\title{
Resistance mechanisms in melanoma to immuneoncologic therapy with checkpoint inhibitors
}

\author{
Sarah E. Fenton, Jeffrey A. Sosman, Sunandana Chandra \\ Division of Hematology Oncology, Northwestern University, Chicago, IL 60611, USA. \\ Correspondence to: Dr. Sunandana Chandra, Division of Hematology Oncology, Northwestern University, 645 N. Michigan Ave, \\ Suite 1006, Chicago, IL 60611, USA. E-mail: sunandana.chandra@northwestern.edu
}

How to cite this article: Fenton SE, Sosman JA, Chandra S. Resistance mechanisms in melanoma to immuneoncologic therapy with checkpoint inhibitors. Cancer Drug Resist 2019;2:744-61. http://dx.doi.org/10.20517/cdr.2019.28

Received: 9 Apr 2019 First Decision: 8 May 2019 Revised: 16 May 2019 Accepted: 22 May 2019 Published: 19 Sep 2019

Science Editor: Helen M. Coley Copy Editor: Cai-Hong Wang Production Editor: Jing Yu

\begin{abstract}
Checkpoint inhibitors act by blocking physiologic mechanisms coopted by tumor cells to evade immune surveillance, restoring the immune system's ability to identify and kill malignant cells. These therapies have dramatically improved outcomes in multiple tumor types with durable responses in many patients, leading to FDA approval first in advanced melanoma, then in many other malignancies. However, as experience with checkpoint inhibitors has grown, populations of patients who are primary nonresponders or develop secondary resistance have been the majority of cases, even in melanoma. Mechanisms of resistance include those inherent to the tumor microenvironment, the tumor cells themselves, and the function of the patient's native immune cells. This review will discuss resistance to checkpoint inhibitors in melanoma as well as possible methods to restore sensitivity.
\end{abstract}

Keywords: Melanoma, checkpoint inhibitor, resistance, nonresponder, secondary resistance

\section{INTRODUCTION}

With 91,270 new cases diagnosed in 2018 and 9,320 fatalities, cutaneous melanoma is the fifth most common cancer in men and the sixth most common cancer in women in the United States. Additionally, due to lifestyle changes and other environmental factors, the incidence of melanoma continues to increase worldwide $^{[1-4]}$. The majority of cases are diagnosed at an early stage and are managed with local excision. However, $30 \%$ of melanomas are diagnosed at a higher stage or progress to metastatic disease ${ }^{[5]}$. These patients require systemic therapy either to prevent recurrence or achieve disease control in hope of

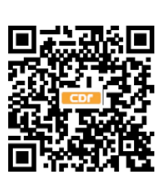


eradication. Prior to 2011, there was a paucity of efficacious therapies available for melanoma. Patients were treated with either dacarbazine or temozolomide, alkylating agents that inhibit DNA synthesis, or high dose interleukin-2 (IL-2), a recombinant analogue that acts to stimulate immune activity against the tumor. These treatments resulted in an overall response rate of $10 \%-20 \%$ with little effect on survival and durable long-term benefit in less than $10 \%$ of patients ${ }^{[6-8]}$. Fortunately, the landscape of systemic therapies for advanced melanoma has dramatically shifted with the introduction of checkpoint inhibitors and B-Raf V600 targeted therapies. Up to $45 \%-65 \%$ of patients treated with checkpoint inhibitors show an initial response $^{[9,10]}$. Forty percent or more do not initially respond to treatment with checkpoint inhibitors due to a mechanism of primary resistance present before the initiation of therapy, these patients are classified as primary nonresponders. Additionally, at least $25 \%-30 \%$ of patients with metastatic melanoma that initially responded to treatment relapse over time through secondary mechanisms of resistance ${ }^{[11]}$. A pooled analysis of stage II and III trials of ipilimumab in advanced melanoma found that at year three approximately $20 \%$ of treated patients maintained disease control. If this positive response was observed, these patients had a high likelihood of maintaining disease control for up to ten years ${ }^{[12]}$. Although significant advances have been made with the introduction of checkpoint inhibitors, it is critical to increase our understanding of these mechanisms of resistance to improve the rates and duration of response. In this review we will discuss both primary and secondary mechanisms of resistance to checkpoint inhibitor therapy in melanoma, as well as treatments under development to restore sensitivity.

\section{TUMOR RECOGNITION AND ANTITUMOR IMMUNE RESPONSE}

Researchers such as Dr. William Coley in 1891 attempted to identify treatment strategies for malignant growths and noted that cancer patients occasionally underwent complete remission when they developed bacterial skin infections ${ }^{[13]}$. These observations suggested that activation of the immune system had unexpected activity not only against the bacteria but against the tumor cells themselves. In the 1950s through the 1970s, Ehrlich, Burnet and Thomas developed the theory of cancer immunosurveillance, suggesting that the immune system may be constantly identifying and targeting abnormal cells for lysis. However, when this immunity is weakened or overtaken by suppressive factors and cells, abnormal cancer cells may escape immune surveillance ${ }^{[14,15]}$. This careful balance is further defined by Dr. Schrieber in his theory of cancer immune-editing, where interaction between the host's natural immunity and malignant cells exists in three phases: elimination, equilibrium, and escape ${ }^{[16,17]}$. Eventually these phases settle to where the immune system is no longer able to recognize the tumor and tumor cells are able to grow unchecked. Further supporting theses hypotheses, mouse studies of established tumors showed that inhibition of the $\mathrm{T}$ cell suppressive pathways resulted in tumor shrinkage ${ }^{[18]}$.

The elimination phase of the cancer immunosurveillance hypothesis is enacted when the immune system recognizes and eliminates malignant cells. One of the defining hallmarks of a cancer cell is its high mutation rate and the generation of abnormal proteins (peptides) from transcripts of mutated DNA, leading to neoantigen formation. Using innate mechanisms of immunosurveillance and response, tumor associated neoantigens can be taken up by antigen presenting cells, presented on their surface bound to MHC complexes and trafficked to lymph nodes where they bind to unique T cell receptors (TCRs) on naïve $\mathrm{T}$ cells. The binding of $\mathrm{CD} 28$ on the $\mathrm{T}$ cell and $\mathrm{B} 7$ on the antigen presenting cell leads to the stimulation and proliferation of the $\mathrm{T}$ cell and secretion of IL-2 to activate downstream immune regulators ${ }^{[1,20]}$. Tumor specific CD8+ T cells differentiate into effector T cells. They then traffic through the circulatory system to the tumor microenvironment where these effector $\mathrm{T}$ cells can identify and kill the tumor cells through perforin mediated lysis, granzyme mediated lysis, and the release of cytokines that induce apoptosis ${ }^{[21,2]}$. Ideally, these effector $\mathrm{T}$ cells then interact with $\mathrm{CD} 4+$ helper $\mathrm{T}$ cells and dendritic cells and differentiate into memory $\mathrm{T}$ cells, creating a durable mechanism of response to future tumor cells expressing the same neoantigen ${ }^{[23]}$. 
The above pathways are utilized by the immune system to recognize and eliminate "non-self", whether these abnormal cells are bacteria or tumor cells. In opposition to this, host cells have also evolved mechanisms to communicate their normalcy to immune cells. Unsurprisingly, tumor cells have in turn coopted these pathways to prevent immune cells from recognizing and eliminating malignant cells $\mathrm{s}^{[24]}$. These changes characterize the equilibrium and escape phases of the cancer immunosurveillance hypothesis ${ }^{[16,17]}$. CTLA-4 is a receptor found on activated effector T cells and T regulatory cells (Tregs), which competes with $\mathrm{CD} 28$ to bind to $\mathrm{B} 7$ on the APC and prevent T cell activation ${ }^{[25,26]}$. Programed death receptor-1 (PD-1) and its ligand (PD-L1 and PD-L2) participate in another checkpoint mechanism for the immune system. PD-1 is expressed on the surface of T cells, monocytes, B cells, dendritic cells and tumor infiltrating lymphocytes (TILs) following initial activation. It is the activated $\mathrm{T}$ cell which has migrated into the tumor microenvironment that secretes $\gamma$-Interferon and induces PD-L1 expression on the tumor cell and surrounding inflammatory myeloid cells. When it binds PD-L1 on the surface of tumor or immune cells, immune tolerance is activated ${ }^{[24,27]}$. Tumor cells are able to coopt these and other pathways to prevent immune recognition and tumor cell targeting. Malignant cells have been shown to upregulate CTLA-4 and PD-L1 expression and downregulate presentation of antigens through genetic and epigenetic changes ${ }^{[2-34]}$. Tumor cells have also developed methods to alter signaling pathways and prevent cytotoxic $\mathrm{T}$ cells from inducing tumor cell death ${ }^{[35]}$. Using these adaptations, malignant cells are able to silence immune surveillance and grow unchecked.

\section{CHECKPOINT INHIBITORS AND THEIR ROLE IN MELANOMA}

Six checkpoint inhibitors (ipilimumab, pembrolizumab, nivolumab, atezolizumab, durvalumab, and avelumab) are currently FDA approved in the treatment of several malignancies including metastatic melanoma, non-small cell lung cancer, renal cell carcinoma, Hodgkin's lymphoma, urothelial cancers, head and neck squamous cell carcinomas, Merkel cell carcinomas and solid tumors with microsatellite instability or mismatch repair gene mutations. These agents act by targeting the CTLA-4 receptor, PD-1 or PD-L1, blocking tumor mediated immune suppression to allow immune recognition of abnormal proteins and immune mediated tumor cell death.

Ipilimumab, a fully human IgG1 monoclonal antibody, binds to CTLA-4 to block its engagement with B7, thereby preventing downregulation of the immune response. A phase III study of ipilimumab vs. a glycoprotein 100 melanoma-specific peptide vaccine in patients with previously treated metastatic or unresectable melanoma showed an overall response rate (ORR) of $10.9 \%$ with ipilimumab monotherapy (1.5\% for the vaccine alone) and overall survival (OS) of 10.1 months with ipilimumab (6.4 months with the vaccine alone $)^{[36]}$. Comparison of ipilimumab and dacarbazine dual therapy with dacarbazine monotherapy showed an overall survival of 11.2 months in the dual therapy group ( $v s .9 .1$ months in the monotherapy group $)^{[37]}$. Based on these trials, ipilimumab was approved by the FDA for the treatment of metastatic melanoma. When all phase II and III trials of ipilimumab in advanced melanoma were pooled for analysis median overall survival with treatment was 11.4 months. The survival curve plateaued at $22 \%$ at three years and continued at similar rates for up to 10 years ${ }^{[12]}$.

Another checkpoint inhibitor, nivolumab is a fully human monoclonal antibody of the IgG4 isotype that acts by binding to $\mathrm{PD}-1$, preventing its interaction with its ligand PD-L1. A phase II trial comparing nivolumab with chemotherapy (institutional standard) in advanced melanoma found an overall response rate of $31.7 \%$ (compared to $10.7 \%$ with chemotherapy) ${ }^{[38]}$. In treatment naïve patients with metastatic melanoma, nivolumab resulted in a one-year overall survival of $72.9 \%$ ( $v s .42 .1 \%$ with dacarbazine), a median progression free survival (PFS) of 5.1 months ( $v s .2 .2$ months with dacarbazine) and an overall response rate of $40 \%$ (vs. $13.9 \%$ with dacarbazine) ${ }^{[39]}$. Combination trials of ipilimumab with nivolumab resulted in response rates of $57.6 \%$ (95\%CI: 52-63) and a median PFS of 11.5 months (95\%CI: 8.9-16.7) in 
the combination therapy group ( $v s$. a RR of $43.7 \%$ (95\%CI: 38.1-49.3) and OS of 9.6 months (95\%CI: $4.3-$ 9.5) with nivolumab alone and a RR of $19 \%$ (95\%CI: 14.9-23.8) and OS of 2.9 months (95\%CI: 2.8-3.4) with ipilimumab alone $)^{[10]}$. Another trial by Wolchok et al ${ }^{[40,41]}$ found that three-year PFS rates for combination nivolumab and ipilimumab were 39\% ( $v s .32 \%$ for nivolumab alone and 10\% for ipilimumab alone) while overall survival rates were $58 \%$ ( $v s .52 \%$ for nivolumab alone and $34 \%$ for ipilimumab alone). Based on these trials and others, nivolumab is FDA approved to treat metastatic melanoma as a monotherapy and in combination with ipilimumab.

Another checkpoint inhibitor used in advanced melanoma is pembrolizumab, a fully human monoclonal IgG4 antibody against PD-1. A study of treatment naïve patients with metastatic melanoma found that pembrolizumab therapy resulted in a longer 3-year PFS compared to ipilimumab (31\%vs. $14 \%$ ). At 4 years overall response rate was $42 \%$ for pembrolizumab vs. $17 \%$ for ipilimumab alone. Rates of overall survival at 4 years were also increased with pembrolizumab therapy $(41.7 \%) v$ s. ipilimumab treatment $(34.1 \%)^{[11,42]}$. Based on these results, pembrolizumab is also FDA approved in the treatment of metastatic melanoma.

More recently, compelling data has been published regarding immunotherapy as an adjuvant treatment in stage III or IV melanoma after resection. Adjuvant ipilimumab therapy increased median recurrence free survival to 26.1 months (95\%CI: 19.3-39.3) compared to 17.1 months (95\%CI: 13.4-21.6) with placebo ${ }^{[43]}$. Rates of recurrence free survival at one year with pembrolizumab monotherapy were $75.4 \%$ (95\%CI: $71.3-$ $78.9)$ vs. $61 \%$ (95\%CI: 56.5-65.1) with placebo ${ }^{[44]}$. Finally, nivolumab adjuvant therapy was found to be superior to ipilimumab monotherapy, with a one-year recurrence free survival rate of $70.5 \%$ (95\%CI: 66.1 74.5) vs. $60.8 \%$ (95\%CI: 56-65.2) with ipilimumab treatment ${ }^{[45]}$. Based on these trials, adjuvant checkpoint inhibitor monotherapy with ipilimumab, nivolumab or pembrolizumab has been approved by the FDA.

\section{RATES OF RESISTANCE WITH CHECKPOINT INHIBITORS}

Two of the most revolutionary contributions of checkpoint inhibitors in the treatment of metastatic melanoma are the high rates of initial response and the ability to induce durable responses in a subset of patients. Unfortunately, rates of primary and secondary resistance remain high. Approximately 45\%-60\% of untreated metastatic melanoma patients treated with PD-1 inhibitors have an initial response, but by three years $43 \%$ of patients will have developed resistance and relapsed with fatal results ${ }^{[10,39,46,47]}$. Over $80 \%$ of melanoma patients treated with CTLA- 4 inhibitor monotherapy have primary resistance ${ }^{[36,37]}$. In the KEYNOTE-001 trial of pembrolizumab, $25 \%$ of patients with an initial response were found to have progression of disease within a median time period of 21 months ${ }^{[9]}$. Another study with pembrolizumab found an initial response rate of $35 \%-40 \%$, this had decreased to $33 \%$ overall survival at 3 years ${ }^{[48]}$. Due to the high rates of primary and secondary resistance, considerable work has been done to understand changes in signaling pathways, immune regulation and the tumor microenvironment to improve response rates and durability after treatment with a checkpoint inhibitor.

\section{MECHANISMS OF PRIMARY RESISTANCE INTRINSIC TO THE TUMOR CELL}

As noted above, between $40 \%-65 \%$ of metastatic melanoma patients do not show an initial response to checkpoint inhibitor mono- or combination therapy and so are categorized as primary nonrespon $\operatorname{ders}^{[10,39,46,47,49-51]}$. Many of these mechanisms of primary resistance result from abnormal interactions between the tumor and immune cells, preventing a successful anti-tumor immune response ${ }^{[22,52,53]}$. For example, lack of expression or presentation of altered antigenic peptides (neoantigens) due to low tumor mutational burden or defects in the antigen presenting machinery reduces recognition of abnormal malignant cells by immune cells ${ }^{[52,54]}$. Loss of function of transporters associated with antigen processing (TAP) proteins, $\beta-2$ microglobulin or silenced HLA expression all prevent the processing and trafficking of antigens to the cell surface ${ }^{[5,56]} \cdot \beta-2$ microglobulin is a component of HLA class 1 , when expression of 
this protein is lost HLA expression and antigen presentation are reduced due to inappropriate folding and transport of the HLA complex to the cell surface ${ }^{[29,57,58]}$. Downregulation of HLA on the tumor cell surface prevents immune mediated tumor cell recognition and killing ${ }^{[59]}$. To date, the tumor types successfully treated with checkpoint inhibitors such as melanoma, bladder cancer, lung cancer and solid tumors with microsatellite instability tend to have higher levels of tumor mutational burden and neoantigen formation ${ }^{[19,60-63]}$. Increased mutational load is associated with an increase in neoantigens with increased response to checkpoint inhibitors, but only if there is an associated increase in CD8+ T cell activation and infiltration ${ }^{[60,64-66]}$. Antigens presented on the tumor surface can be derived from viral antigens, nonmutated proteins where T-cell tolerance is incomplete (ex. MAGE-type antigens) and non-synonymous mutations that produce neoantigens ${ }^{[19,67-69]}$. Genetic and epigenetic changes in neoantigen expression can restrict $\mathrm{T}$ cells from recognizing abnormal antigens, inhibiting activation of the immune response $\mathrm{e}^{[21,28-31]}$. Additionally, tumors with early expression of immunosuppressive pathways such as PD-L1 are protected from immune mediated recognition and elimination, resulting in an immune protected state. These cells are associated with higher rates of neoantigen production and increased susceptibility to immune attack once these immunosuppressive checkpoints are inhibited or reversed ${ }^{[70]}$. Finally, Giannakis et al ${ }^{[71]}$ found mutations clustered in the TCR binding domain of the HLA protein in colon cancer, suggesting that successful cancer cells are clonally selected for their ability to escape $\mathrm{T}$ cell recognition through decreased antigen presentation. Hypermethylation of the HLA genes leading to decreased expression has also been identified in melanoma ${ }^{[72-75]}$.

Tumor cells can also bypass immune cell-mediated elimination through changes in apoptosis pathways activated by the immune effector cell ${ }^{[76]}$. For example, mutations in the interferon $\gamma$ pathway can prevent apoptosis and tumor cell death ${ }^{[5,56]}$. Interferon $\gamma$ signaling can be reduced through many pathways; however, one of the predominant mechanisms found in melanoma is loss of PTEN expression. Identified in $30 \%$ of melanomas, loss of PTEN expression resulted in increased PI3K signaling and decreased interferon $\gamma$ and granzyme B expression by antigen specific T cells. Decreased interferon $\gamma$ blocks recruitment of other immune cells and the induction of anti-proliferative and pro-apoptotic signaling in the tumor cells ${ }^{[77-81]}$. These changes are associated with poor response to $\mathrm{PD}-1$ inhibitors ${ }^{[77]}$. A case report of a patient with a near complete response to PD-1 inhibition showed that one resistant lesion had biallelic loss of PTEN ${ }^{[77]}$. Interferon $\gamma$ mediates some of its effect through JAK and STAT1 signaling. Through this same mechanism, loss of function mutations in JAK1 or JAK2 result in loss of interferon $\gamma$ signaling, again preventing immune cell-mediated killing of the malignant cells ${ }^{[27,29,82]}$. In a small study of primary nonresponders, $75 \%$ of patients resistant to CTLA-4 inhibitors had a mutation in the interferon $\gamma$ pathway or were found to have alternative changes leading to upregulation of negative regulators of the interferon $\gamma$ pathway ${ }^{[81]}$. Deletion of interferon $\gamma$ receptors, JAK1, JAK2 and STAT1 in mice with melanoma resulted in loss of PD-L1 expression and resistance to PD- 1 inhibition ${ }^{[83]}$. Downregulation of other inducers of apoptosis such as caspase- 8 and TRAIL can also allow evasion of immune-cell mediated cell death ${ }^{[84,85]}$. Acting through an inverse mechanism, increased expression of pro-survival genes such as BCL2 or BCL-XL in melanoma cells are associated with blockade of immune mediated apoptosis and cell killing ${ }^{[76]}$.

Expression of a specific subset of genes, called the innate anti-PD-1 resistance signature or IPRES, is associated with transformation of melanoma cells to a mesenchymal subtype, a reversion back to a more stem-cell like phenotype ${ }^{[86,87]}$. Upregulation of these genes may be caused by inflammation in the tumor microenvironment, and drives increased tumor plasticity. These genes are associated with resistance to checkpoint inhibitor therapy ${ }^{[87,88]}$. Upregulation of other specific genes associated with the epithelial to mesenchymal transition such as AXL, TWIST2, WNT5a, LOXL2, ROR2, TAGLN and FAP are also associated with primary resistance to $\mathrm{PD}-\mathrm{L} 1$. This may be through the induction of a more plastic phenotype and upregulation of TNF- $\alpha^{[87,89]}$. 
Thus far therapies have been developed to block two checkpoints for immune activation: CTLA4 and PD-1/PD-L1. However, other immune checkpoints exist and can be upregulated by tumor cells resulting in resistance to ipilimumab, nivolumab, and pembrolizumab therapy. These alternative checkpoints include the LAG-2 gene, TIM-3 (the T cell immunoreceptor that contains the immunoglobulin and ITIM domains), CD160, BTLA and V domain mediated immunoglobulin suppressors. These inhibitors of T cell activation and function have been studied in metastatic melanoma as well as head and neck, metastatic ovarian, prostate cancer and lung adenocarcinoma ${ }^{[79,90-94]}$.

\section{MECHANISMS OF PRIMARY RESISTANCE ASSOCIATED WITH THE TUMOR MICROENVIRONMENT}

As discussed above, there are several characteristics intrinsic to tumor cells that lead to primary resistance to checkpoint inhibitors. However, features of the tumor microenvironment and immune system are also associated with decreased or absent response to checkpoint inhibitor therapy ${ }^{[95,96]}$. Patients with notable responses to these drugs tend to have higher densities of CD8+ T-cells in the melanoma tumor prior to treatment ${ }^{[97,98]}$. Localization of immune cells within the tumor as opposed to at the tumor margin or complete absence from the tumor is associated with favorable results after checkpoint inhibitor exposure $^{[99]}$. Response is also associated with the density of $\mathrm{T}$ cell and macrophage influx into the tumor microenvironment after treatment is initiated ${ }^{[2,100-106]}$. Lack of sufficient breadth or depth of $\mathrm{T}$ cells primed to recognize and react against specific tumor antigens results in poor immunogenicity after checkpoint inhibitor therapy ${ }^{[52]}$. In fact, the ability to recognize neoantigens as non-self is likely as important to the success of checkpoint inhibitor therapy that the actual number of mutations and neoantigens expressed on the cell surface ${ }^{[107-109]}$. Mechanisms that inhibit $\mathrm{T}$ cell proliferation and the priming of naïve $\mathrm{T}$ cells can result in a limited pool of available $\mathrm{T}$ cells and decreased antigen recognition ${ }^{[101,110,111]}$. Specifically, downregulation of MHC proteins on dendritic cells prevents antigen presentation and immune cell activation, limiting response to checkpoint inhibitors ${ }^{[59,112-116]}$. Dendritic cell function is primarily decreased in the tumor microenvironment through tumor mediated expression of IL-37b and STAT3 (which activates VEGF, IL-10 and TGF- $\beta)^{[117-121]}$. Downregulation of immune cell recruitment through signals such as CXCR3 can also decrease $\mathrm{T}$ cell homing to the tumor site ${ }^{[122]}$.

Tumor cells can prevent $\mathrm{T}$ cells and other immune cells from entering the tumor microenvironment. Mechanisms of $\mathrm{T}$ cell exclusion include MAPK signaling, $\beta$-catenin stabilization, expression of a mesenchymal transcriptome and PD-L1 expression ${ }^{[55,56]}$. Upregulation of MAPK signaling increases VEGF and IL-8 production, inhibiting $\mathrm{T}$ cell recruitment and function ${ }^{[123]}$. Increased $\beta$-catenin signaling results in upregulation of WNT signaling and reduced dendritic cell and T cell recruitment, handicapping the ability of immune cells to act within the tumor microenvironment ${ }^{[101,124,125]}$. Melanoma tumors with increased infiltration by CD8+ T cells and low $\beta$-catenin signaling were associated with longer PFS ${ }^{[125]}$. Additionally, upregulation of EZH2 expression causes CXCL9 and CXCL10 downregulation, decreasing $\mathrm{T}$ cell recruitment to the tumor, and promotes the tumor cells to undergo transformation to a more mesenchymal phenotype $e^{[126-132]}$. Inhibition of this pathway is associated with increased immunogenicity and $\mathrm{T}$ cell infiltration in mouse melanoma tumors ${ }^{[133]}$.

Apart from lack of immune cell infiltration, the recruitment of regulatory or suppressive immune cells also determines refractoriness to immunotherapy. Tregs can suppress the function of other immune cells in the microenvironment through secretion of IL- 6 , IL-10, IL-35 and TGF- $\beta$, as well as through direct inhibitory contact with other $\mathrm{T}$ cells. This creates an immune tolerant environment through increased Treg recruitment and inhibition of $\mathrm{T}$ effector cell function ${ }^{[52,134-138]}$. Tumor associated macrophages express $\mathrm{PD}-\mathrm{L} 1$ and $\mathrm{B} 7-\mathrm{H}_{4}$ to downregulate $\mathrm{T}$ cell responses ${ }^{[139-142]}$. The presence of myeloid derived suppressor cells (MDSCs) has also been associated with poor response to immunotherapy ${ }^{[143-145]}$. In fact, levels of MDSCs 
may be used as a predictive marker of response to ipilimumab therapy in metastatic melanoma ${ }^{[143]}$. These cells are recruited in response to IL-6, IL-10 and TGF- $\beta$ secretion by the tumor cells to downregulate tumor antigen recognition, prevent $\mathrm{T}$ cell proliferation and inhibit cytotoxic $\mathrm{T}$ cell function ${ }^{[137,138]}$. Finally, cancer associated fibroblasts express TGF- $\beta$, reducing T cell infiltration into the tumor environment through a similar mechanism as Treg cells ${ }^{[97,146-148]}$.

Upregulation of Fas ligand on intratumoral blood vessels through VEGF-mediated proangiogenic signaling by the tumor is another mechanism that reduces immune cell trafficking into the tumor microenvironment ${ }^{[149,150]}$. The presence of the Fas ligand induces apoptosis of Fas $+\mathrm{CD} 8+\mathrm{T}$ cells when they come in contact with the pericyte wrapped around the blood vessel during migration. Tregs remain unaffected and traffic freely into the melanoma tumor. Upregulation of the Fas ligand is highly specific to blood vessels within the tumor, as it is often not seen in surrounding tissue ${ }^{[151]}$. Increased expression of the endothelin-B receptor may play a similar role, decreasing the recruitment of TILs ${ }^{[152,153]}$. Acting through a separate pathway, VEGF also upregulates NF- $\mathrm{\kappa B}$ signaling, limiting dendritic cell maturation and antigen presentation $^{[154-156]}$.

Due to the high metabolic demands of the malignant cells, the tumor microenvironment is an environment that may block adequate immune cell function. Tumor cells and T cells often compete for necessary metabolic substrates such as glucose, cholesterol, and specific amino acids such as arginine and glutamine ${ }^{[35,157-159]}$. Additionally, the tumor microenvironment tends to be highly acidic with increased concentration of tumor derived lactate and hypoxia from malignant cell consumption, reducing $\mathrm{T}$ cell function due to their dependence on aerobic glycolysis ${ }^{[157,160-166]}$. Unfortunately, Tregs are not as dependent on the presence of these factors and their function is likely less limited in the tumor microenvironment, adding to the overall immunosuppression ${ }^{[21]}$. Finally, hypoxia induces ATP release into the tumor microenvironment. Dephosphorylation of ATP to adenosine results in ligation of the adenosine with the $\mathrm{A} 2 \mathrm{~A}$ receptor on $\mathrm{T}$ effector cells, blocking their function ${ }^{[161]}$.

Expression of inflammatory signaling molecules such as TGF- $\beta$, indolamine-2,3-dioxygenase (IDO), IL-10, and arginase by stromal cells and leukocytes within the tumor also suppresses immune cell function ${ }^{[167-171]}$. IDO expression specifically catabolizes tryptophan to kynurenine to inhibit dendritic cell function, block T cell proliferation, and increase MDSC and Treg infiltration ${ }^{[171-178]}$.

Finally, as in most other areas of the body, the tumor microenvironment involves a microbial component. These microbes act through Toll like receptor signaling to alter the infiltration of monocytes, reducing immune responses and the efficacy of checkpoint inhibitors ${ }^{[179,180]}$. Additionally, microbial metabolism and fermentation of fibers generate butyrate in the tumor microenvironment. As cancer cells cannot use butyrate for energy, competition for resources between microbes and cancer cells may inhibit malignant growth. Butyrate can also act as a histone deacetylase inhibitor to promote apoptosis and inhibit proliferation ${ }^{[181]}$. Bifidobacterium in the microenvironment is associated with increased dendritic cell function and mouse models show inhibition of melanoma when Bifidobacterium is present ${ }^{[182]}$. Similar results have been seen with Bacteroides fragilis and Bacteroides thetaiotamicron in other models where cytotoxic T-cell function is augmented in the presence of these bacteria ${ }^{[183-185]}$. Although the above mechanisms may have an anticancer effect, researchers have also identified roles for the microbiota that may promote tumor growth including local inflammation and tissue damage. Extrapolating from microbe's role during infection, it is also possible that bacteria in the microenvironment promote angiogenesis ${ }^{[186]}$. Additionally, upregulation of $\mathrm{T}$ helper cells in the microenvironment is associated with tumorigenesis in colorectal cancer ${ }^{[187]}$. More specifically, the presence of Fusobacterium nucleatum has been associated with silencing of cytotoxic T cells, upregulation of MDSCs and increased tumor associated macrophages in the microenvironment ${ }^{[188,189]}$. 


\section{MECHANISMS OF SECONDARY RESISTANCE}

A significant proportion of melanoma patients treated with checkpoint inhibitors exhibits an initial response. Fortunately, for a subset of patients these responses are durable and long lasting. However, the majority of patients experience relapse and the development of secondary resistance mechanisms. The majority of these mechanisms are similar to those found in primary nonresponders. Exposure to checkpoint inhibitors drives selection for tumor cells that have developed escape mechanisms or may alter immune cell functioning to prevent successful malignant cell elimination. One primary mechanism of secondary resistance is downregulation of antigen presentation on the tumor cell surface ${ }^{[28,32,33]}$. This may be mediated by upregulation of interferon $\gamma$ signaling after checkpoint inhibitor exposure ${ }^{[190]}$. A study of relapsed nonsmall cell lung tumors by Anagnostou et al. ${ }^{[191]}$ found that on average 7-18 potential neonatigens were lost after treatment with checkpoint mono- or combination therapy. These neoantigens were associated with stronger anti-tumor responses than those that were retained, suggesting selective immunoediting.

Specific mutations have also been identified in melanoma cells after the development of secondary resistance. A late relapse patient with metastatic melanoma resistant to CTLA-4 inhibition was found to have biallelic loss of $\beta$-2-microglobulin ${ }^{[29,110]}$. Zaretsky et al. ${ }^{[29]}$ also identified a patient with homozygous frameshift deletions of $\beta$-2-microglobulin that had developed resistance to PD-1 blockade ${ }^{[28-30,192]}$. Five patients treated with immunotherapy were found to have reduced MHC expression and were not recognized by effector $\mathrm{T}$ cells due to loss of $\beta$-2-microglobulin expression. Three of these patients were known to have normal $\beta$-2-microglobulin expression prior to treatment ${ }^{[58]}$. Acquired resistance to PD- 1 inhibitors has also been associated with inactivating mutations in JAK1 and JAK2, leading to escape from interferon $\gamma$ signaling and immune-mediated tumor cell death ${ }^{[29,82]}$. Four melanoma patients treated with pembrolizumab were found to have loss of function mutations in JAK1/2 in relapsed tumors ${ }^{[29]}$.

Similar to mechanisms of primary resistance, secondary processes are associated with changes in the balance between immune effector and repressor cells in the tumor microenvironment. Study of resistant melanomas suggest that they have reversed back to a T cell excluded state ${ }^{[29]}$. CTLA-4 and PD-1/PD-L1 inhibition is also associated with upregulation of other inhibitory pathways such as EZH2, LAG-3, TIM-3, TIGIT and VISTA, silencing immune activity through another mechanism ${ }^{[79,93,177,193,194]}$. Finally, VEGF is upregulated in relapsed patients, suggesting secondary resistance may also occur through Fas ligand and other VEGF-mediated mechanisms ${ }^{[97]}$.

\section{MECHANISMS OF IMMUNE CELL EXHAUSTION AND LACK OF MEMORY CELL FORMATION}

Activation of the immune response is associated with upregulation of innate immune suppressors to prevent an uncontrolled immune reaction. Therefore, treatment with checkpoint inhibitors and persistent immune activation can lead to an exhausted $\mathrm{T}$ cell phenotype with upregulation of surface receptors such as LAG-3 and TIM-3 among others and ultimately result in treatment failure ${ }^{[27,92,195-197]}$.

Interestingly, expression of PD-L1 is associated with signaling to promote effector T cell exhaustion. Treatment with PD-1/PD-L1 inhibition may reverse this exhaustion phenotype and rescue T cell function, however this change is not associated with the expected next steps of memory $\mathrm{T}$ cell formation, limiting the duration of anti-tumor response ${ }^{[23,102-105,198-200]}$. CTLA-4 inhibition, on the other hand, is associated with expansion of effector $\mathrm{T}$ cells that express alternative immune checkpoints and result in further immunosuppression ${ }^{[92,94,201]}$.

Studies of gene expression profiles within tumors using single cell RNA sequencing technology confirm these findings. Lack of Tcf7 expression, a protein involved in the differentiation and persistence of memory T-cells, is associated with resistance to treatment with checkpoint inhibitors. Together this data suggests 
that the formation of memory $\mathrm{T}$ cells is a critical component of patient responses when treated with immunotherapy and failure of this pathway is associated with drug resistance $e^{[202,203]}$.

\section{MECHANISMS OF RESISTANCE ASSOCIATED WITH THE PATIENT}

Interestingly, factors outside of the tumor cells themselves and the microenvironment that they thrive in have been associated with checkpoint inhibitor failure. A stool microbiome enriched with bacteria from the Raecalibacterium genus and other firmicutes is associated with increased progression free and overall survival after treatment with ipilimumab, as well as higher rates of immune mediated colitis ${ }^{[204]}$. Metastatic melanoma patients with higher gut microbiome diversity also have a higher density of intratumoral effector $\mathrm{T}$ cells after checkpoint inhibitor exposure ${ }^{[204,205]}$. Recent antibiotic use and associated reductions in gut microbiome diversity has been associated with resistance in renal cell carcinoma treatment with anti$\mathrm{PD}-1, \mathrm{PD}-\mathrm{L} 1$ and combination therapies ${ }^{[206]}$. Although the exact mechanism underlying this association is unknown, it may be due to increased priming of dendritic cells with antigens that cross-react with tumor neoantigens ${ }^{[182,207,208]}$. The bulk of the research done on interactions between the gut microbiome and checkpoint inhibitors has been performed in mice. As this research is applied to patients and the human gut microbiome a more nuanced approach is likely required, as both the presence of melanoma and the use of checkpoint inhibitors is associated with shifts in the balance between different phylum of bacteria in the gut $^{[209,210]}$. Whether these changes are a driver of resistance or the result of other mechanisms of resistance at play has not yet been established.

Finally, certain clinical findings are associated with primary nonresponse to checkpoint inhibitor therapy. An elevated serum neutrophil to lymphocyte ratio is associated with poor survival following checkpoint inhibitor therapy while an overall low neutrophil count and low LDH is associated with increased survival $^{[165,211]}$. In another study of patients with metastatic melanoma treated with pembrolizumab, a high serum eosinophil and lymphocyte count and a low LDH was associated with increased survival ${ }^{[164]}$. High tumor burden at the time of treatment initiation is also associated with primary resistance ${ }^{[6,212,213]}$.

\section{NOVEL THERAPIES TO BYPASS RESISTANCE}

Due to the high demand for effective systemic therapies for metastatic melanoma and recent advances with PD-1 and CTLA-4 inhibitors, significant work is ongoing to reduce rates of primary and secondary resistance to these drugs. The majority of these investigations focus on reversing specific mutations and pathways known to be associated with treatment failure. For example, JAK1/2 inhibitors are associated with overcoming resistance ${ }^{[79]}$. Alternatively, the introduction of agonists for proteins downstream of JAK1/2 such as STAT1 may also restore immune activity ${ }^{[29,214,215]}$. Anti-angiogenic drugs have been shown to improve lymphocyte trafficking and migration as well as reverse immunotherapy resistance ${ }^{[77,216,217]}$. VEGF inhibition in melanoma is associated with increased levels of TILs through increased CXCL10 and 11, inhibition of prostaglandin E2 also restores effector $\mathrm{T}$ cell infiltration ${ }^{[218,219]}$. Treatment with 5 -azacitadine may reverse hypermethylation of MHC genes, restoring antigen presentation ${ }^{[220-223]}$. Adding Lag-3 inhibitors has been associated with tumor regression and increased survival in mice, the addition of a poxvirus to this regimen is also associated with improved responses in mice ${ }^{[224,25]}$. Dual blockade of TIM-3 and PD-L1 or CTLA-4 is associated with tumor response and increased T cell function ${ }^{[226,227]}$.

Beyond reversing specific pathways or mutations associated with checkpoint inhibitor failure, combination therapy with other drugs is being explored to alter more general changes to improve checkpoint inhibitor efficacy. Adding indoleamine inhibitors to treatment strategies could help relieve metabolic rate limiting steps in the tumor microenvironment ${ }^{[21]}$. Checkpoint inhibitor failure has been associated with the development of an exhausted immune phenotype; and adding histone deacetylase inhibitors, epigenetic modifying agents (ex. disease modifying anti-rheumatic drugs or DMARDs) or targeted therapies for 
the exhaustion pathways may prolong the response to immunotherapy and antigen presentation ${ }^{[104,105,228]}$. Finally, adding IDO inhibitors such as the peptide vaccine formulated against IDO, indoximod or epacadostat may restore the efficacy of immunotherapy ${ }^{[229-231]}$.

Clinicians and researchers are also improving the efficacy of checkpoint inhibitors by optimizing the immune response induced by PD- 1 and CTLA- 4 blockade. Essentially, these therapies are acting to turn a "cold" tumor microenvironment into a "hot" tumor microenvironment where the immune system is active against the malignant cells. Increasing the ability to upregulate effector $\mathrm{T}$ cells or downregulate Tregs would dramatically improve responses and decrease rates of resistance ${ }^{[52,134-136]}$. Combination therapies proposed to alter the interaction between the immune system and tumor include agents such as cyclophosphamide or oxaliplatin to increase the priming of effector T cells, PI3K $\gamma$ to inhibit myeloid suppressor cells, CSF-1R inhibitors to downregulate tumor associated macrophages and TGF- $\beta$ inibitors to downregulate Tregs ${ }^{[35,139-145,232-236]}$. Recent work with single cell RNA sequencing methods have identified programs of gene expression within the tumor associated with poor response to checkpoint inhibitors. Further study of these gene expression patterns suggest that treatment with CDK4/6 inhibitors may shift the tumor cells to a less immune resistant state, increasing response to checkpoint blockade ${ }^{[237]}$. Priming MHC class II receptors could potentially increase CD4+ T cell activity, bypassing difficulties seen with MHC I inhibition in melanoma cells with $\beta-2$ microglobulin and other mutations ${ }^{[238]}$. The addition of cancer vaccines (with either peptide vaccines or with primed dendritic cell vaccines) or the additional of radiation therapy to increase neoantigen formation and recognition may augment $\mathrm{T}$ cell responses and tumor recognition ${ }^{[35,239-242]}$. Similarly, adding cytokines that stimulate the immune system such as IFN-a, IL-2, IL-12, IL-10 and the granulocyte-macrophage colony-stimulating factor (GM-CSF) to the treatment regimen or at high concentrations directly into the tumor microenvironment may also alter immune responses ${ }^{[243]}$.

Finally, adding probiotics to a patient's treatment regimen may increase drug efficacy and treatment response. This has been successfully shown to improve responses in mouse models of melanoma ${ }^{[182]}$. However, this data remains controversial as recent studies have shown that melanoma patients tend to have a lower diversity within the gut microbiome than healthy patients and that probiotic use further decreased this diversity. These findings suggest that probiotic use may be more complex than previously understood and may not be as directly associated with improved outcomes ${ }^{[210]}$.

\section{CONCLUSION}

Resulting in nearly 10,000 deaths per year, melanoma presents a significant challenge for cancer researchers and clinicians ${ }^{[1]}$. Fortunately, recent years have seen a revolution in melanoma therapy with the introduction of checkpoint inhibitors. Despite the significant improvement in outcomes, rates of primary resistance and relapse remain high in melanoma patients treated with checkpoint inhibitors. Therefore, diverse approaches detailed in this review are being pursued to improve clinical outcomes and their duration. These include novel treatment strategies that target mutations within the tumors themselves, mechanisms that inhibit an adequate immune response to tumor cells, changes within the tumor microenvironment and factors present in the patient to improve the efficacy of checkpoint inhibitor mono- and dual therapy.

\section{DECLARATIONS}

\section{Authors' contributions}

Contributed substantially to the research, writing and reviewing of this article: Fenton SE, Sosman JA, Chandra S

\section{Availability of data and materials}

Not applicable. 


\section{Financial support and sponsorship}

None.

\section{Conflicts of interest}

All authors declared that there are no conflicts of interest.

\section{Ethical approval and consent to participate}

Not applicable.

\section{Consent for publication}

Not applicable.

\section{Copyright}

(C) The Author(s) 2019.

\section{REFERENCE}

1. Mansfield AS, Nevala WK, Leiser EA, Leontovich AA, Markovic SN. The immunomodulatory effects of bevacizumab on systemic immunity in patients with metastatic melanoma. Oncoimmunology 2013;2:e24436.

2. Emmett MS, Dewing D, Pritchard-Jones RO. Angiogenesis and melanoma - from basic science to clinical trials. Am J Cancer Res 2011;1:852-68.

3. Siegel RL, Miller KD, Jemal A. Cancer statistics, 2016. CA Cancer J Clin 2016;66:7-30.

4. Siegel RL, Miller KD, Jemal A. Cancer statistics, 2018. CA Cancer J Clin 2018;68:7-30.

5. Tas F. Metastatic behavior in melanoma: timing, pattern, survival, and influencing factors. J Oncol 2012;2012:647684.

6. Carbone PP, Costello W. Eastern cooperative oncology group studies with DTIC (NSC-45388). Cancer Treat Rep 1976; 60:193-8.

7. Atkins MB, Lotze MT, Dutcher JP, Fisher RI, Weiss G, et al. High-dose recombinant interleukin 2 therapy for patients with metastatic melanoma: analysis of 270 patients treated between 1985 and 1993. J Clin Oncol 1999;17:2105-16.

8. Luke JJ, Flaherty KT, Ribas A, Long GV. Targeted agents and immunotherapies: optimizing outcomes in melanoma. Nat Rev Clin Oncol 2017; 14:463-82

9. Ribas A, Hamid O, Daud A, Hodi FS, Wolchok JD, et al. Association of pembrolizumab with tumor response and survival among patients with advanced melanoma. JAMA 2016;315:1600-9.

10. Larkin J, Hodi FS, Wolchok JD. Combined nivolumab and ipilimumab or monotherapy in untreated melanoma. N Engl J Med 2015;373:1270-1.

11. Schachter JRA, Long GV, Arance A, Grob JJ, Mortier L, et al. Pembrolizumab versus ipilimumab for advanced melanoma: final overall survival analysis of KEYNOTE-006. Lancet Oncol 2017;390:1853-62.

12. Schadendorf D, Hodi FS, Robert C, Weber JS, Margolin K, et al. Pooled analysis of long-term survival data from phase II and phase III trials of ipilimumab in unresectable or metastatic melanoma. J Clin Oncol 2015;33:1889-94.

13. La-Beck NM, Jean GW, Huynh C, Alzghari SK, Lowe DB. Immune checkpoint inhibitors: new insights and current place in cancer therapy. Pharmacotherapy 2015;35:963-76.

14. Ehrlich P. Collected papers in four volumes including a complete bibliography. London: Pergamon Press; 1956.

15. Burnet FM. Immunological surveillance in neoplasia. Transplant Rev 1971;7:3-25.

16. Dunn GP, Bruce AT, Ikeda H, Old LJ, Schreiber RD. Cancer immunoediting: from immunosurveillance to tumor escape. Nat Immunol 2002;3:991-8.

17. Schreiber RD, Old LD, Smyth MJ. Cancer immunoediting: integrating immunity's roles in cancer suppression and promotion. Science 2011;331:1565-70.

18. Leach DR, Krummel MF, Allison JP. Enhancement of antitumor immunity by CTLA-4 blockade. Science 1996;271:1734-6.

19. Schumacher TN, Schreiber RD. Neoantigens in cancer. Science 2015;348:69-74

20. Ishida Y, Agata Y, Shibahara K, Honjo T. Induced expression of PD-1, a novel member of the immunoglobulin gene superfamily, upon programmed cell death. EMBO 1992;11:3887-95.

21. Syn NL, Teng MWL, Mok TSK, Soo RA. De-novo and acquired resistance to immune checkpoint targeting. Lancet Oncol 2017;18:e731-41.

22. O’Donnell JS, Long GV, Scolyer RA, Teng MW, Smyth MJ. Resistance to PD/PDL1 checkpoint inhibition. Cancer Treat Rev 2017;52:71-81.

23. Ribas A, Shin DS, Zaretsky J, Frederiksen J, Cornish A, et al. PD-1 blockade expands intratumoral memory T cells. Cancer Immunol Res 2016;4:194-203.

24. Keir ME, Butte MJ, Freeman GJ, Sharpe AH. PD-1 and its ligands in tolerance and immunity. Annu Rev Immunol 2008;26:677-704.

25. Krummel MF, Allison JP. CD28 and CTLA-4 have opposing effects on the response of T cells to stimulation. J Exp Med 1995;182:459-65. 
26. Brunet JF, Denizot F, Luciani MF, Roux-Dosseto M, Suzan M, et al. A new member of the immunoglobulin superfamily--CTLA-4. Nature 1987;328:267-70.

27. Pardoll DM. The blockade of immune checkpoints in cancer immunotherapy. Nat Rev Cancer 2012;12:252-64.

28. Rooney MS, Shukla SA, Wu CJ, Getz G, Hacohen N. Molecular and genetic properties of tumors associated with local immune cytolytic activity. Cell 2015;160:48-61.

29. Zaretsky JM, Garcia-Diaz A, Shin DS, Escuin-Ordinas H, Hugo W, et al. Mutations associated with acquired resistance to PD-1 blockade in melanoma. N Engl J Med 2016;375:819-29.

30. Zhao F, Sucker A, Horn S, Heeke C, Bielefeld N, et al. Melanoma lesions independently acquire T-cell resistance during metastatic latency. Cancer Res 2016;76:4347-58.

31. Wang X, Schoenhals JE, Li A, Valdecanas DR, Ye H, et al. Suppression of type I IFN signaling in tumors mediates resistance to anti-PD-1 treatment that can be overcome by radiotherapy. Cancer Res 2017;77:839-50.

32. Matsushita H, Vesely MD, Koboldt DC, Rickert CG, Uppaluri R, et al. Cancer exome analysis reveals a T-cell-dependent mechanism of cancer immunoediting. Nature 2012;482:400-4.

33. Verdegaal EM, de Miranda NF, Visser M, Harryvan T, van Buuren MM, et al. Neoantigen landscape dynamics during human melanoma-T cell interactions. Nature 2016;536:91-5.

34. Arenas-Ramirez N, Sahin D, Boyman O. Epigenetic mechanisms of tumor resistance to immunotherapy. Cell Mol Life Sci 2018;75:4163-76.

35. Pitt JM, Vetizou M, Daillere R, Roberti MP, Yamazaki T, et al. Resistance mechanisms to immune-checkpoint blockade in cancer: tumour-intrinsic and -extrinsic factors. Immunity 2016;44:1255-69.

36. Hodi FS, O'Day SJ, McDermott DF, Weber RW, Sosman JA, et al. Improved survival with ipilimumab in patients with metastatic melanoma. N Engl J Med 2010;363:711-23.

37. Robert C, Thomas L, Bondarenko I, O’Day S, Weber J, et al. Ipilimumab plus dacarbazine for previously untreated metastatic melanoma. N Engl J Med 2011;364:2517-26.

38. Weber JS, D’Angelo SP, Minor D, Hodi FS, Gutzmer R, et al. Nivolumab versus chemotherapy in patients with advanced melanoma who progressed after anti-CTLA-4 treatment (CheckMate 037): a randomised, controlled, open-label, phase 3 trial. Lancet Oncol 2015; $16: 375-84$.

39. Robert C, Long GV, Brady B, Dutriaux C, Maio M, et al. Nivolumab in previously untreated melanoma without BRAF mutation. N Engl J Med 2015;372:320-30.

40. Wolchok JD, Kluger H, Callahan MK, Postow MA, Rizvi NA, et al. Nivolumab plus ipilimumab in advanced melanoma. N Engl J Med 2013;369:122-33.

41. Wolchok JD, Chiarion-Sileni V, Gonzalez R, Rutkowski P, Grob JJ, et al. Overall survival with combined nivolumab and ipilimumab in advanced melanoma. N Engl J Med 2017;377:1345-56.

42. Long GV, Schachter J, Ribas A, Arance AM, Grob JJ, et al. 4-year survival and outcomes after cessation of pembrolizumab (pembro) after 2-years in patients (pts) with ipilimumab (ipi)-naïve advanced melanoma in KEYNOTE-006. J Clin Oncol 2018;36:Abstract 9503.

43. Eggermont AM, Chiarion-Sileni V, Grob JJ, Dummer R, Wolchok JD, et al. Adjuvant ipilimumab versus placebo after complete resection of high-risk stage III melanoma (EORTC 18071): a randomized, double-blind, phase 3 trial. Lancet Oncol 2015;16:522-30.

44. Eggermont AMM, Blank CU, Mandala M, Long GV, Atkinson V, et al. Adjuvant pembrolizumab versus placebo in resected stage III melanoma. N Engl J Med 2018;378:1789-801.

45. Weber J, Mandala M, Del Vecchio M, Gogas HJ, Arance AM, et al. CheckMate 238 Collaborators. Adjuvant nivolumab versus ipilimumab in resected stage III or IV melanoma. N Engl J Med 2017;377:1824-35.

46. Robert C, Schachter J, Long GV, Arance A, Grob JJ, et al. Pembrolizumab versus ipilimumab in advanced melanoma. N Engl J Med 2015;372:2521-32.

47. Robert C, Ribas A, Hamid O, Daud A, Wolchok JD, et al. Three-year overall survival for patients with advanced melanoma treated with pembrolizumab in KEYNOTE-001. J Clin Oncol 2016;34:abstr 9503.

48. Ribas A, Hamid O, Daud A, Hodi FS, Wolchok JD, et al. Association of pembrolizumab with tumor response and survival among patients with advanced melanoma. JAMA 2016;315:1600-9.

49. Carlino MS, Atkinson V, Cebon JS. KEYNOTE-029: efficacy and safety of pembrolizumab (pembro) plus ipilimumab (ipi) for advanced melanoma. J Clin Oncol 2017;35:9545.

50. Hodi FS, Chesney J, Pavlick AC, Robert C, Grossmann KF, et al. Combined nivolumab and ipilimumab versus ipilimumab alone in patients with advanced melanoma: 2-year overall survival outcomes in a multicentre, randomised, controlled, phase 2 trial. Lancet Oncol 2016;17:1558-68.

51. Topalian SL, Hodi FS, Brahmer JR, Gettinger SN, Smith DC, et al. Safety, activity, and immune correlates of anti-PD-1 antibody in cancer. N Engl J Med 2012;366:2443-54.

52. Sharma P, Hu-Lieskovan S, Wargo JA, Ribas A. Primary, adaptive and acquired resistance to cancer immunotherapy. Cell 2017;168:70723.

53. Jenkins RW, Barbie DA, Flaherty KT. Mechanisms of resistance to immune checkpoint inhibitors. Br J Cancer 2018;118:9-16.

54. Gubin MM, Zhang X, Schuster H, Caron E, Ward JP, et al. Checkpoint blockade cancer immunotherapy targets tumour-specific mutant antigens. Nature 2014;515:577-81.

55. Marincola FM, Jaffee EM, Hicklin DJ, Ferrone S. Escape of human solid tumors from T-cell recognition: molecular mechanisms and functional significance. Adv Immunol 2000;74:181-273. 
56. Sucker A, Zhao F, Real B, Heeke C, Bielefeld N, et al. Genetic evolution of T-cell resistance in the course of melanoma progression. Clin Cancer Res 2014;20:6593-604.

57. D'Urso CM, Wang ZG, Cao Y, Tatake R, Zeff RA, et al. Lack of HLA class I antigen expression by cultured melanoma cells FO-1 due to a defect in B2m gene expression. J Clin Invest 1991;87:284-92.

58. Restifo NP, Marincola FM, Kawakami Y, Taubenberger J, Yannelli JR, et al. Loss of functional beta 2-microglobulin in metastatic melanomas from five patients receiving immunotherapy. J Natl Cancer Inst 1996;88:100-8.

59. Ward PL, Koeppen HK, Hurteau T, Rowley DA, Schreiber H. Major histocompatibility complex class I and unique antigen expression by murine tumors that escaped from CD8+ T-cell-dependent surveillance. Cancer Res 1990;50:3851-8.

60. Van Allen EM, Miao D, Schilling B, Shukla SA, Blank C, et al. Genomic correlates of response to CTLA-4 blockade in metastatic melanoma. Science 2015;350:207-11.

61. Lawrence MS, Stojanov P, Polak P, Kryukov GV, Cibulskis K, et al. Mutational heterogeneity in cancer and the search for new cancerassociated genes. Nature 2013;499:214-8.

62. Le DT, Durham JN, Smith KN, Wang H, Bartlett BR, et al. Mismatch-repair deficiency predicts response of solid tumours to PD-1 blockade. Science 2017;357:409-13.

63. Le DT, Uram JN, Wang H, Bartlett BR, Kemberling H, et al. PD-1 blockade in tumours with mismatch-repair deficiency. N Engl J Med 2015;372:2509-20.

64. Snyder A, Makarov V, Merghoub T, Yuan J, Zaretsky JM, et al. Genetic basis for clinical response to CTLA-4 blockade in melanoma. N Engl J Med 2014;371:2189-99.

65. McGranahan N, Furness AJS, Rosenthal R, Ramskov S, Lyngaa R, et al. Clonal neoantigens elicit T cell immunoreactivity and sensitivity to immune checkpoint blockade. Science 2016;351:1463-9.

66. Reuben A, Spencer CN, Prieto PA, Gopalakrishnan V, Reddy SM, et al. Genomic and immune heterogeneity are associated with differential responses to therapy in melanoma. NPJ Genom Med 2017;2:10.

67. Alexandrov LB, Nik-Zainal S, Wedge DC, Aparicio SA, Behjati S, et al. Signatures of mutational processes in human cancer. Nature 2013;500:415-21.

68. Rizvi NA, Hellmann MD, Snyder A, Kvistborg P, Makarov V, et al. Cancer immunology. Mutational landscape determines sensitivity to PD-1 blockade in non-small cell lung cancer. Science 2015;348:124-8.

69. Coulie PG, Van den Eynde JB, van der Bruggen P, Boon T. Tumour antigens recognized by T lymphocytes: at the core of cancer immunotherapy. Nat Rev Cancer 2014;14:135-46.

70. Martin AM, Nirschl TR, Nirschl CJ, Francica BJ, Kochel CM, et al. Paucity of PD-L1 expression in prostate cancer: innate and adaptive immune resistance. Prostate Cancer Prostatic Dis 2015;18:325-32.

71. Giannakis M, Mu XJ, Shukla SA, Qian ZR, Cohen O, et al. Genomic correlates of immune-cell infiltrates in colorectal carcinoma. Cell Rep 2016;15:857-65.

72. Scanlan MJ, Gure AO, Jungbluth AA, Old LJ, Chen YT. Cancer/testis antigens: an expanding family of targets for cancer immunotherapy. Immunol Rev 2002;188:22-32.

73. James SR, Link PA, Karpf AR. Epigenetic regulation of X-linked cancer/germline antigen genes by DNMT1 and DNMT3b. Oncogene 2006;25:6975-85.

74. Yu J, Zhang H, Gu J, Lin S, Li J, et al. Methylation profiles of thirty four promoter-CpG islands and concordant methylation behaviours of sixteen genes that may contribute to carcinogenesis of astrocytoma. BMC Cancer 2004;4:65.

75. Yu J, Ni M, Xu J, Zhang H, Gao B, et al. Methylation profiling of twenty promoter-CpG islands of genes which may contribute to hepatocellular carcinogenesis. BMC Cancer 2002;2:29.

76. Andersen MH, Becker JC, Straten PT. Regulators of apoptosis: suitable targets for immune therapy of cancer. Nat Rev Drug Discov 2005;4:399-409.

77. Peng W, Chen JQ, Liu C, Malu S, Creasy C, et al. Loss of PTEN promotes resistance to T cell-mediated immunotherapy. Cancer Discov 2016;6:202-16.

78. Platanias LC. Mechanisms of type-I- and type-II-interferon-mediated signalling. Nature Rev Immunol 2005;5:375-86.

79. Benci JL, Xu B, Qiu Y, Wu TJ, Dada H, et al. Tumor interferon signaling regulates a multigenic resistance program to immune checkpoint blockade. Cell 2016;167:1540-54.e12.

80. Shankaran V, Ikeda H, Bruce AT, White JM, Swanson PE, et al. IFNgamma and lymphocytes prevent primary tumour development and shape tumour immunogenicity. Nature 2001;410:1107-11.

81. Gao J, Shi LZ, Zhao H, Chen J, Xiong L, et al. Loss of IFN- $\gamma$ pathway genes in tumor cells as a mechanism of resistance to anti-CTLA-4 therapy. Cell 2016;167:397-404.

82. Shin DS, Zaretsky JM, Escuin-Ordinas H, Garcia-Diaz A, Hu-Lieskovan S, et al. Primary resistance to PD-1 blockade mediated by JAK1/2 mutations. Cancer Discov 2017;7:188-201.

83. Manguso RT, Pope HW, Zimmer MD, Brown FD, Yates KB, et al. In vivo CRISPR screening identifies Ptpn2 as a cancer immunotherapy target. Nature 2017;547:413-8.

84. Hopkins-Donaldson S, Ziegler A, Kirtz S, Bigosch C, Kandioler D, et al. Silencing of death receptor and caspase-8 expression in small cell lung carcinoma cell lines and tumors by DNA methylation. Cell Death Differ 2003;10:356-64.

85. Eramo A, Pallini R, Lotti F, Sette G, Patti M, et al. Inhibition of DNA methylation sensitizes glioblastoma for tumor necrosis factorrelated apoptosis-inducing ligand-mediated destruction. Cancer Res 2005;65:11469-77.

86. Hugo W, Shi H, Sun L, Piva M, Song C, et al. Non-genomic and immune evolution of melanoma acquiring MAPKi resistance. Cell 
2015; 162:1271-85.

87. Hugo W, Zaretsky JM, Sun L, Song C, Moreno BH, et al. Genomic and transcriptomic features of response to anti-PD-1 therapy in metastatic melanoma. Cell; $165: 35-44$.

88. Ayers M, Lunceford J, Nebozhyn M, Murphy E, Loboda A, et al. IFN-gamma-related mRNA profile predicts clinical response to PD-1 blockade. J Clin Invest 2017;127:2930-40.

89. Falletta P, Sanchez-del-Campo L, Chauhan J, Effern M, Kenyon A, et al. Translation reprogramming is an evolutionarily conserved driver of phenotypic plasticity and therapeutic resistance in melanoma. Genes Dev 2017;31:18-33.

90. Shayan G, Srivastava R, Li J, Schmitt N, Kane LP, et al. Adaptive resistance to anti-PD1 therapy by Tim-3 upregulation is mediated by the PI3K-Akt pathway in head and neck cancer. Oncoimmunology 2016;6:e1261779.

91. Huang RY, Francois A, McGray AR, Miliotto A, Odunsi K. Compensatory upregulation of PD-1, LAG-3, and CTLA-4 limits the efficacy of single-agent checkpoint blockade in metastatic ovarian cancer. Oncoimmunology 2016;6:e1249561.

92. Koyama S, Akbay EA, Li YY, Herter-Spri GS, Buczkowski KA, et al. Adaptive resistance to therapeutic PD-1 blockade is associated with upregulation of alternative immune checkpoints. Nat Commun 2016;17:10501.

93. Gao J, Ward JF, Pettaway CA, Shi LZ, Subudhi SK, et al. VISTA is an inhibitory immune checkpoint that is increased after ipilimumab therapy in patients with prostate cancer. Nat Med 2017;23:551-5.

94. Thommen DS, Schreiner J, Muller P, Herzig P, Roller A, et al. Progression of lung cancer is associated with increased dysfunction of T cells defined by coexpression of multiple inhibitory receptors. Cancer Immunol Res 2015;3:1344-55.

95. Rao SV, Moran AE, Graff JN. Predictors of response and resistance to checkpoint inhibitors in solid tumors. Ann Transl Med 2017;5:468.

96. Pullari B, Kumar A, Shaheen M, Jeter J, Sundarajan S. Tumor microenvironment changes leading to resistance of immune checkpoint inhibitors in metastatic melanoma and strategies to overcome resistance. Pharmacol Res 2017;123:95-102.

97. Chen W, Ten Dijke P, Immunoregulation by members of the TGF $\beta$ superfamily. Nat Rev Immunol 2016;16:723-40.

98. Powderly JD, Koeppen H, Hodi FS, Sosman JA, Gettinger SN, et al. Biomarkers and associations with the clinical activity of PD-L1 blockade in a MPDL3280A study. J Clin Oncol 2013;31:abstr 3001.

99. Chen DS, Mellman I. Elements of cancer immunity and the cancer-immune set point. Nature 2017;541:321-30.

100. Vilain RE, Menzies AM, Wilmott JS, Kakavand H, Madore J, et al. Dynamic changes in PD-L1 expression and immune infiltrates early during treatment predict response to PD-1 blockade in melanoma. Clin Cancer Res 2017;23:5024-33.

101. Spranger S, Bao R, Gajewski TF. Melanoma-intrinsic beta-catenin signalling prevents anti-tumour immunity. Nature 2015;523:231-5.

102. Pauken KE, Sammons MA, Odorizzi PM, Manne S, Godec J, et al. Epigenetic stability of exhausted T cells limits durability of reinvigoration by PD-1 blockade. Science 2016;354:1160-5.

103. Sen DR, Kaminski J, Barnitz RA, Kurachi M, Gerdemann U, et al. The epigenetic landscape of T cell exhaustion. Science 2016;354:1165-9.

104. Ngiow SF, Young A, Blake SJ, Hill GR, Yagita H, et al. Agonistic CD40 mAb-driven IL12 reverses resistance to anti-PD1 in a T-cell-rich tumor. Cancer Res 2016;76:6266-77.

105. Mognol GP, Spreafico R, Wong V, Scott-Browne JP, Togher S, et al. Exhaustion-associated regulatory regions in CD8 + tumor-infiltrating T cells. Proc Natl Acad Sci USA 2017;114:E2776-85.

106. Huang AC, Postow MA, Orlowski RJ, Mick R, Bengsch B, et al. T-cell invigoration to tumour burden ratio associated with anti-PD-1 response. Nature 2017;545:60-5.

107. Łuksza M, Riaz N, Makarov V, Balachandran VP, Hellmann MD, et al. A neoantigen fitness model predicts tumour response to checkpoint blockade immunotherapy. Nature 2017;551:517-20.

108. Balachandran VP, Łuksza M, Zhao JN, Makarov V, Moral JA, et al. Identification of unique neoantigen qualities in long-term survivors of pancreatic cancer. Nature 2017;551:512-6.

109. Galluzzi L, Vitale E, Aaronson SA, Abrams JM, Adam DP, et al. Molecular mechanisms of cell death: Recommendations of the Nomenclature Committee on Cell Death 2018. Cell Death Differ 2018;25:486-541.

110. Roh W, Chen PL, Reuben A, Spencer CN, Prieto PA, et al. Integrated molecular analysis of tumor biopsies on sequential CTLA-4 and PD-1 blockade reveals markers of response and resistance. Sci Transl Med 2017;9:eaah3560.

111. Winograd R, Byrne KT, Evans RA, Odorizzi PM, Meyer AR, et al. Induction of T-cell immunity overcomes complete resistance to PD-1 and CTLA-4 blockade and improves survival in pancreatic carcinoma. Cancer Immunol Res 2015;3:399-411.

112. Ni K, O’Neill HC. The role of dendritic cells in T cell activation. Immunol Cell Biol 1997;75:223-30.

113. Korkolopoulou P, Kaklamanis L, Pezzella F, Harris AL, Gatter KC. Loss of antigen-presenting molecules (MHC class I and TAP-1) in lung cancer. Br J Cancer 1996;73:148-53.

114. Kelderman S, Schumacher TN, Haanen JB. Acquired and intrinsic resistance in cancer immunotherapy. Mol Oncol 2014;8:1132-9.

115. Restifo NP, Smyth MJ, Snyder A. Acquired resistance to immunotherapy and future challenges. Nat Rev Cancer 2016;16:121-6.

116. Jager E, Ringhoffer M, Altmannsberger M, Arand M, Karbach J, et al. Immunoselection in vivo: independent loss of MHC class I and melanocyte differentiation antigen expression in metastatic melanoma. Int J Cancer 1997;71:142-7.

117. Wu W, Wang W, Wang Y, Li W, Yu G, et al. IL-37b suppresses T cell priming by modulating dendritic cell maturation and cytokine production via dampening ERK/NF-kappaB/S6K signalings. Acta Biochim Biophys Sin (Shanghai) 2015;47:597-603.

118. Emeagi PU, Maenhout S, Dang N, Heirman C, Thielemans K, et al. Downregulation of Stat3 in melanoma: reprogramming the immune microenvironment as an anticancer therapeutic strategy. Gene Ther 2013;20:1085-92.

119. Chattopadhyay G, Shevach EM. Antigen-specific induced T regulatory cells impair dendritic cell function via an IL-10/MARCH1dependent mechanism. J Immunol 2013;191:5875-84. 
120. Hargadon KM, Bishop JD, Brandt JP, Hand ZC, Ararso YT, et al. Melanoma-derived factors alter the maturation and activation of differentiated tissue-resident dendritic cells. Immunol Cell Biol 2016;94:24-38.

121. Lindenberg JJ, van de Ven R, Lougheed SM, Zomer A, Santegoets SJAM, et al. Functional characterization of a STAT3-dependent dendritic cell-derived CD14+ cell population arising upon IL-10-driven maturation. OncoImmunology 2013;2:e23837. [PMID: 23734330 DOI: 10.4161/onci.23837]

122. Hong M, Puaux AL, Huang C, Loumagne L, Tow C, et al. Chemotherapy induces intratumoral expression of chemokines in cutaneous melanoma, favoring T-cell infiltration and tumor control. Cancer Res 2011;71:6997-7009.

123. Liu C, Peng W, Xu C, Lou Y, Zhang M, et al. BRAF inhibition increases tumor infiltration by T cells and enhances the antitumor activity of adoptive immunotherapy in mice. Clin Cancer Res 2013;19:393-403.

124. Spranger S, Dai D, Horton B, Gajewski TF. Tumor-residing Batf3 dendritic cells are required for effector T cell trafficking and adoptive T cell therapy. Cancer Cell 2017;31:711-23.

125. Massi D, Romano E, Rulli E, Merelli B, Nassini R, et al. Baseline $\beta$-catenin, programmed death-ligand 1 expression and tumourinfiltrating lymphocytes predict response and poor prognosis in BRAF inhibitor-treated melanoma patients. Eur J Cancer 2017;78:70-81.

126. van Vierken LE, Kiefer CM, Morehouse C, Li Y, Groves C, et al. EZH2 is required for breast and pancreatic cancer stem cell maintenance and can be used as a functional cancer stem cell reporter. Stem Cells Transl Med 2013;2:43-52.

127. Adhikary G, Grun D, Balasubramanian S, Kerr C, Huang JM, et al. Survival of skin cancer stem cells requires the Ezh2 polycomb group protein. Carcinogenesis 2015;36:800-10.

128. Zingg D, Debbache J, Schaefer SM, Tuncer E, Frommer SC, et al. The epigenetic modifier EZH2 controls melanoma growth and metastasis through silencing of distinct tumour suppressors. Nat Commun 2015;6:6051.

129. Cao Q, Yu J, Dhanasekaran SM, Kim JH, Mani RS, et al. Repression of E-cadherin by the polycomb group protein EZH2 in cancer. Oncogene 2008;27:7274-84.

130. Ma DN, Chai ZT, Zhu XD, Zhang N, Zhan DH, et al. MicroRNA-26a suppresses epithelial-mesenchymal transition in human hepatocellular carcinoma by repressing enhancer of zeste homolog 2. J Hematol Oncol 2016;9:1.

131. Peng D, Kryczek I, Nagarsheth N, Zhao L, Wei S, et al. Epigenetic silencing of TH1-type chemokines shapes tumour immunity and immunotherapy. Nature 2015;527:249-53.

132. Nagarsheth N, Peng D, Kryczek I, Wu K, Li W, et al. PRC2 epigenetically silences Th1-type chemokines to suppress effector T-cell trafficking in colon cancer. Cancer Res 2016;76:275-82.

133. Zingg D, Arenas-Ramirez N, Sahin D, Rosalia RA, Antunes AT, et al. The histone methyltransferase Ezh2 controls mechanisms of adaptive resistance to tumor immunotherapy. Cell Rep 2017;20:854-67.

134. Oida T, Zhang X, Goto M, Hachimura S, Totsuka M, et al. CD4+CD25- T cells that express latency-associated peptide on the surface suppress CD4+CD45RBhigh-induced colitis by a TGF-beta-dependent mechanism. J Immunol 2003;170:2516-22.

135. Sakaguchi S, Yamaguchi T, Nomura T, Ono M. Regulatory T cells and immune tolerance. Cell 2008;133:775-87.

136. Sundstedt A, O’Neill EJ, Nicolson KS, Wraith DC. Role for IL-10 in suppression mediated by peptide-induced regulatory T cells in vivo. J Immunol 2003;170:1240-8.

137. Reichel J, Chadburn A, Rubinstein PG, Giulino-Roth L, Tam W, et al. Flow sorting and exome sequencing reveal the oncogenome of primary Hodgkin and Reed-Sternberg cells. Blood 2015;125:1061-72.

138. Guo F, Wang Y, Liu J, Mok SC, Xue F, et al. CXCL12/CXCR4: a symbiotic bridge linking cancer cells and their stromal neighbors in oncogenic communication networks. Oncogene 2015;35:816-26.

139. Kuang DM, Zhao Q, Peng C, Xu J, Zhang JP, et al. Activated monocytes in peritumoral stroma of hepatocellular carcinoma foster immune privilege and disease progression through PD-L1. J Exp Med 2009;206:1327-37.

140. Kryczek I, Zou L, Rodriguez P, Zhu G, Wei S, et al. B7-H4 expression identifies a novel suppressive macrophage population in human ovarian carcinoma. J Exp Med 2006;203:871-81.

141. Le DT, Lutz E, Uram JN, Sugar EA, Onners B, et al. Evaluation of ipilimumab in combination with allogeneic pancreatic tumor cells transfected with a GM-CSF gene in previously treated pancreatic cancer. J Immunother 2013;36:382-9.

142. Zhu Y, Knolhoff BL, Meyer MA, Nywening TM, West BL, et al. CSF1/CSF1R blockade reprograms tumor-infiltrating macrophages and improves response to T-cell checkpoint immunotherapy in pancreatic cancer models. Cancer Res 2014;74:5057-69.

143. Meyer C, Cagnon L, Costa-Nunes CM, Baumgaertner P, Montandon N, et al. Frequencies of circulating MDSC correlate with clinical outcome of melanoma patients treated with ipilimumab. Cancer Immunol Immunother 2014;63:247-57.

144. De Henau O, Rausch M, Winkler D, Campesato LF, Liu C, et al. Overcoming resistance to checkpoint blockade therapy by targeting PI3Kgamma in myeloid cells. Nature 2016;539:443-7.

145. Kaneda MM, Messer KS, Ralainirina N, Li H, Leem CJ, et al. PI3Kgamma is a molecular switch that controls immune suppression. Nature 2016;539:437-42.

146. Mariathasan S, Turley SJ, Nickles D, Castiglioni A, Yuen K, et al. TGF $\beta$ attenuates tumour response to PD-L1 blockade by contributing to exclusion of T cells. Nature 2018;554:544-8.

147. Tauriello DVF, Palomo-Ponce S, Stork D, Berenguer-Llergo A, Badia-Ramentol J, et al. TGF $\beta$ drives immune evasion in genetically reconstituted colon cancer metastasis. Nature 2018;554:538-43.

148. Ravi R, Noonan KA, Pham V, Bedi R, Zhavoronkov A, et al. Bifunctional immune checkpoint-targeted antibody-ligand traps that simultaneously disable TGF $\beta$ enhance the efficacy of cancer immunotherapy. Nat Commun 2018;9:741.

149. Zhang L, Conejo-Garcia JR, Katsaros D, Gimotty PA, Massobrio M, et al. Intratumoral T cells, recurrence, and survival in epithelial ovarian cancer. N Engl J Med 2003;348:203-13. 
150. Schaaf MB, Garg AD, Agostinis P. Defining the role of the tumor vasculature in antitumor immunity and immunotherapy. Cell Death Dis 2018;9:115.

151. Motz GT, Santoro SP, Wang LP, Garrabrant T, Lastra RR, et al. Tumor endothelium FasL establishes a selective immune barrier promoting tolerance in tumors. Nat Med 2014;20:607-15.

152. Demunter A, De Wolf-Peeters C, Degreef H, Stas M, van den Oord JJ. Expression of the endothelin-B receptor in pigment cell lesions of the skin. Evidence for its role as tumor progression marker in malignant melanoma. Virchows Arch 2001;438:485-91.

153. Buckanovich RJ, Facciabene A, Kim S, Benencia F, Sasaroli D, et al. Endothelin B receptor mediates the endothelial barrier to T cell homing to tumors and disables immune therapy. Nat Med 2008;14:28-36.

154. Ellis LM, Hicklin DJ. VEGF-targeted therapy: mechanisms of anti-tumor activity. Nat Rev Cancer 2008;8:579-91.

155. Young MR, Wright MA, Coogan M, Young ME, Bagash J. Tumor-derived cytokines induce bone marrow suppressor cells that mediate immunosuppression through transforming growth factor beta. Cancer Immunol Immunother 1992;35:14-8.

156. Commeren DL, Van Soest PL, Karimi K, Lowenberg B, Cornelissen JJ, et al. Paradoxical effects of interleukin-10 on the maturation of murine myeloid dendritic cells. Immunology 2003;110:188-96.

157. Delgoffe GM. Filling the tank: keeping antitumor T cells metabolically fit for the long haul. Cancer Immunol Res 2016;4:1001-6.

158. Barsoum IB, Smallwood CA, Siemens DR, Graham CH. A mechanism of hypoxia-mediated escape from adaptive immunity in cancer cells. Cancer Res 2014;74:665-74.

159. Scharping NE, Menk AV, Moreci RS, Whetstone RD, Dadey RE, et al. The tumor microenvironment represses $\mathrm{T}$ cell mitochondrial biogenesis to drive intratumoral T cell metabolic insufficiency and dysfunction. Immunity 2016;45:701-3.

160. Brand A, Singer K, Koehl GE, Kolitzus M, Schoenhammer G, et al. LDHA-associated lactic acid production blunts tumor immunosurveillance by T and NK cells. Cell Metab 2016;24:657-71.

161. Young A, Mittal D, Stagg H, Smyth MH. Targeting cancer-derived adenosine: new therapeutic approaches. Cancer Discov 2014;4:87988.

162. Blank CU, Haanen JB, Ribas A, Schumacher TN. Cancer immunology. The "cancer immunogram". Science 2016;352:658-60.

163. Fischer K, Hoffmann P, Voelkl S, Meidenbauer N, Ammer J, et al. Inhibitory effect of tumor cell-derived lactic acid on human T cells. Blood 2017; 109:3812-9

164. Weide B, Martens A, Hassel JC, Berking C, Postow MA, et al. Baseline biomarkers for outcome of melanoma patients treated with pembrolizumab. Clin Cancer Res 2016;22:5487-96.

165. Diem S, Kasenda B, Spain L, Martin-Liberal J, Marconcini R, et al. Serum lactate dehydrogenase as an early marker for outcome in patients treated with anti-PD-1 therapy in metastatic melanoma. Br J Cancer 2016;114:256-61.

166. Zimmer L, Apuri S, Eroglu Z, Kottschade LA, Forschner A, et al. Ipilimumab alone or in combination with nivolumab after progression on anti-PD-1 therapy in advanced melanoma. Eur J Cancer 2017;75:47-55.

167. Gorelik L, Flavell RA. Immune-mediated eradication of tumors through the blockade of transforming growth factor-beta signaling in $\mathrm{T}$ cells. Nat Med 2001;7:1118-22.

168. Grohmann U, Fallarino F, Puccetti P. Tolerance, DCs and tryptophan: much ado about IDO. Trends Immunol 2003;24:242-8.

169. Curiel TJ, Coukos G, Zou L, Alvarez X, Cheng P, et al. Specific recruitment of regulatory T cells in ovarian carcinoma fosters immune privilege and predicts reduced survival. Nat Med 2004;10:942-9.

170. Rodriguez PC, Quiceno DG, Zabaleta J, Ortiz B, Zea AH, et al. Arginase I production in the tumor microenvironment by mature myeloid cells inhibits T-cell receptor expression and antigen-specific T-cell responses. Cancer Res 2004;64:5839-49.

171. Platten M, von Knebel Doeberitz N, Oezen I, Wick W, Ochs K. Cancer immunotherapy by targeting IDO1/TDO and their downstream effectors. Front Immunol 2015;5:673.

172. Mondanelli G, Bianchi R, Pallotta MT, Orabona C, Albini E, et al. A relay pathway between arginine and tryptophan metabolism confers immunosuppressive properties on dendritic cells. Immunity 2017;46:233-44.

173. Holmgaard RB, Zamarin D, Munn DH, Wolchok JD, Allison JP. Indoleamine 2,3-dioxygenase is a critical resistance mechanism in antitumor T cell immunotherapy targeting CTLA-4. J Exp Med 2013;210;1389-402.

174. Holmgaard RB, Zamarin D, Li Y, Gasmi B, Munn DH, et al. Tumor-expressed IDO recruits and activates MDSCs in a Treg-dependent manner. Cell Rep 2015;13:412-24.

175. Uyttenhove C, Pilotte L, Theate I, Stroobant V, Colau D, et al. Evidence for a tumoral immune resistance mechanism based on tryptophan degradation by indoleamine 2,3-dioxygenase. Nat Med 2003;9:1269-74.

176. Munn DH, Shafizadeh E, Attwood JT, Bondarev I, Pashine A, et al. Inhibition of T cell proliferation by macrophage tryptophan catabolism. J Exp Med 1999;189:1363-72.

177. Spranger S, Spaapen RM, Zha Y, Williams J, Meng Y, et al. Up-regulation of PD-L1, IDO, and T(regs) in the melanoma tumor microenvironment is driven by CD8(+) T cells. Sci Transl Med 2013;5:200ra116.

178. Spranger S, Koblish HK, Horton B, Scherle PA, Newton R, et al. Mechanism of tumor rejection with doublets of CTLA-4, PD-1/PD-L1, or IDO blockade involves restored IL-2 production and proliferation of $\mathrm{CD} 8(+) \mathrm{T}$ cells directly within the tumor microenvironment. J Immunol Ther Cancer 2014;2:3.

179. Pushalkar S, Hundeyin M, Daley D, Zambirinis CP, Kurz E, et al. The pancreatic cancer microbiome promotes oncogenesis by induction of innate and adaptive immune suppression. Cancer Discov 2018;8:403-16.

180. Mitsuhashi D, Nosho K, Sukawa Y, Matsunaga Y, Ito M, et al. Association of Fusobacteriumspecies in pancreatic cancer tissues with molecular features and prognosis. Oncotarget 2015;6:7209-20.

181. Fulbright LE, Ellermann M, Arthur JC. The microbiome and the hallmarks of cancer. PLoS Pathog 2017;13:e1006480. 
182. Sivan A, Corrales L, Hubert N, Williams JB, Aquino-Michaels K, et al. Commensal Bifidobacterium promotes antitumor immunity and facilitates anti-PD-L1 efficacy. Science 2015;350:1084-9.

183. Vetizou M, Pitt JM, Daillere R, Lepage P, Waldschmitt N, et al. Anticancer immunotherapy by CTLA-4 blockade relies on the gut microbiota. Science 2015;350:1079-84.

184. Mazmanian SK, Liu CH, Tzianabos AO, Kasper DL. An immunomodulatory molecule of symbiotic bacteria directs maturation of the host immune system. Cell 2005;122: 107-18.

185. Mazmanian SK, Round JL, Kasper DL. A microbial symbiosis factor prevents intestinal inflammatory disease. Nature 2008;453:620-5.

186. Osherov N, Ben-Ami R. Modulation of host angiogenesis as a microbial survival strategy and therapeutic target. PLoS Pathog 2016;12:e1005479-8.

187. Grivennikov SI, Wang K, Mucida D, Stewart CA, Schnabl B, et al. Adenoma-linked barrier defects and microbial products drive IL-23/ IL-17-mediated tumour growth. Nature 2012;491:254-8.

188. Gur C, Ibrahim Y, Isaacson B, Yamin R, Abed J, et al. Binding of the Fap2 protein of fusobacterium nucleatum to human inhibitory receptor TIGIT protects tumors from immune cell attack. Immunity 2015;42:344-55.

189. Kostic AD, Chun E, Robertson L, Glickman JN, Gallini CA, et al. Fusobacterium nucleatum potentiates intestinal tumorigenesis and modulates the tumor-immune microenvironment. Cell Host Microbe 2013;14:207-15.

190. Takeda K, Nakayama M, Hayakawa Y, Kojima Y, Ikeda H, et al. IFN- $\gamma$ is required for cytotoxic T cell-dependent cancer genome immunoediting. Nat Commun 2017;8:14607.

191. Anagnostou V, Smith KN, Forde PM, Niknafs N, Bhattacharya R, et al. Evolution of neoantigen landscape during immune checkpoint blockade in non-small cell lung cancer. Cancer Discov 2017;7:264-76.

192. Pereira C, Gimenez-Xavier P, Pros E, Pajares MJ, Moro M, et al. Genomic profiling of patient-derived xenografts for lung cancer identifies B2M inactivation impairing immunorecognition. Clin Cancer Res 2016;23:3203-13.

193. Arenas-Ramirez N, Woytschak J, Boyman O. Interleukin-2: biology, design and application. Trends Immunol 2015;36:763-77.

194. Arenas-Ramirez N, Zou C, Popp S, Zingg D, Brannetti B, et al. Improved cancer immunotherapy by a CD25-mimobody conferring selectivity to human interleukin-2. Sci Transl Med 2016;8:367ra166.

195. Topalian SL, Drake CG, Pardoll DM. Immune checkpoint blockade: a common denominator approach to cancer therapy. Cancer Cell 2015;27:450-61.

196. Wherry EJ. T cell exhaustion. Nat Immunol 2011;12:492-9.

197. Sznol M, Chen L. Antagonist antibodies to PD-1 and B7-H1 (PD-L1) in the treatment of advanced human cancer. Clin Cancer Res 2013;19:1021-34

198. Gide TN, Wilmott JS, Scolyer RA, Long GV. Primary and acquired resistance to immune checkpoint inhibitors in metastatic melanoma. Clin Cancer Res 2018;24:1260-70.

199. Wherry EJ, Kurachi M. Molecular and cellular insights into T cell exhaustion. Nat Rev Immunol 2015;15:486-99.

200. Shin H, Wherry EJ. CD8 T cell dysfunction during chronic viral infection. Curr Opin Immunol 2007;19:408-15.

201. Wei SC, Levine JH, Cogdill AP, Zhao Y, Anang NAS, et al. Distinct cellular mechanisms underlie anti-CTLA-4 and anti-PD-1 checkpoint blockade. Cell 2017;170:1120-33.e17.

202. Sade-Feldman M, Yizhak K, Bjorgaard SL, Ray JP, de Boer CG, et al. Defining T cell states associated with response to checkpoint immunotherapy in melanoma. Cell 2018;175:998-1013.

203. Kurtulus S, Madi A, Escobar G, Klapholz M, Nyman J, et al. Checkpoint blockade immunotherapy induces dynamic changes in PD-1CD8+ tumor-infiltrating T cells. Immunity 2019;50:181-94.

204. Chaput N, Lepage P, Coutzac C, Soularue E, Le Roux K, et al. Baseline gut microbiota predicts clinical response and colitis in metastatic melanoma patients treated with ipilimumab. Ann Oncol 2017;28:1368-79.

205. Wargo JA, Gopalakrishnan V, Spencer C, Karpinets T, Reuben A, et al. Association of the diversity and composition of the gut microbiome with responses and survival (PFS) in metastatic melanoma (MM) patients (pts) on anti-PD-1 therapy. J Clin Oncol 2017;35:abstr3008.

206. Derosa L, Routy B, Enot D, Baciarello G, Massard C, et al. Impact of antibiotics on outcome in patients with metastatic renal cell carcinoma treated with immune checkpoint inhibitors. Proc Am Soc Clin Oncol 2017;35:abstr462.

207. Vétizou M, Pitt JM, Daillère R, Lepage P, Waldschmitt N, et al. Anticancer immunotherapy by CTLA-4 blockade relies on the gut microbiota. Science 2015;350:1079-84.

208. Zitvogel L, Ayyoub M, Routy B, Kroemer G. Microbiome and anticancer immunosurveillance. Cell 2016;165:276-87.

209. Humphries A, Daud A. The gut microbiota and immune checkpoint inhibitors. Hum Vaccin Immunother 2018;14:2178-82.

210. McQuade JL, Gopalakrishnan V, Spencer C, Andrews MC, Helmink B, et al. The gut microbiome of melanoma patients is distinct from that of healthy individuals and is impacted by probiotic and antibiotic use. SMR Congress Abstracts 2018 Dec.

211. Valpione S, Martinoli C, Fava P, Mocillin S, Capgana LG, et al. Personalised medicine: development and external validation of a prognostic model for metastatic melanoma patients treated with ipilimumab. Eur J Cancer 2015;51:2086-94.

212. Nishino M, Giobbie-Hurder A, Manos MP, Bailey N, Buchbinder EI, et al. Immune-related tumor response dynamics in melanoma patients treated with pembrolizumab: identifying markers for clinical outcome and treatment decisions. Clin Cancer Res 2017;23:4671-9.

213. Tumeh PC, Harview CL, Yearley JH, Shintaku IP, Taylor EJ, et al. PD-1 blockade induces responses by inhibiting adaptive immune resistance. Nature 2014;515:568-71.

214. Corrales L, McWhirter SM, Dubensky TW Jr, Gajewski TF. The host STING pathway at the interface of cancer and immunity. J Clin Invest 2016;126:2404-11. 
215. Fu H, Kishore M, Gittens B, Wang G, Coe D, et al. Self-recognition of the endothelium enables regulatory T-cell trafficking and defines the kinetics of immune regulation. Nat Commun 2014;5:3436.

216. Lee JM, Cimino-Mathews A, Peer CJ, Zimmer A, Lipkowitz S, et al. Safety and clinical activity of the programmed death-ligand 1 inhibitor durvalumab in combination with poly (ADP-ribose) polymerase inhibitor olaparib or vascular endothelial growth factor receptor 1-3 inhibitor cediranib in women's cancers: a dose-escalation, phase I study. J Clin Oncol 2017;35:2193-202.

217. Wallin JJ, Bendell JC, Funke R, Sznol M, Korski K, et al. Atezolizumab in combination with bevacizumab enhances antigen-specific T-cell migration in metastatic renal cell carcinoma. Nat Commun 2016;7:12624.

218. Bouzin C, Brouet A, De Vriese J, DeWever J, Feron O. Effects of vascular endothelial growth factor on the lymphocyte-endothelium interactions: identification of caveolin-1 and nitric oxide as control points of endothelial cell anergy. J Immunol 2007;178:1505-11.

219. Terme M, Pernot S, Marcheteau E, Sandoval F, Benhamouda N, et al. VEGFA-VEGFR pathway blockade inhibits tumor-induced regulatory T-cell proliferation in colorectal cancer. Cancer Res 2013;73:539-49.

220. Smith HA, Cronk RJ, Lang JM, McNeel DG. Expression and immunotherapeutic targeting of the SSX family of cancer-testis antigens in prostate cancer. Cancer Res 2011;71:6785-95.

221. Weber J, Salgaller M, Samid D, Johnson B, Herlyn M, et al. Expression of the MAGE-1 tumor antigen is up-regulated by the demethylating agent 5-aza-2'-deoxycytidine. Cancer Res 1994;54:1766-71.

222. Dubovsky JA, McNeel DG. Inducible expression of a prostate cancer-testis antigen, SSX-2, following treatment with a DNA methylation inhibitor. Prostate 2007;67:1781-90.

223. Goodyear O, Agathanggelou A, Novitzky-Basso I, Siddique S, McSkeane T, et al. Induction of a CD8+ T-cell response to the MAGE cancer testis antigen by combined treatment with azacitidine and sodium valproate in patients with acute myeloid leukemia and myelodysplasia. Blood 2010;116:1908-18.

224. Woo SR, Turnis ME, Goldberg MV, Bankoti J, Selby M, et al. Immune inhibitory molecules LAG-3 and PD-1 synergistically regulate T-cell function to promote tumoral immune escape. Cancer Res 2012;72:917-27.

225. Foy SP, Sennino B, dela Cruz T, Cote JJ, Gordon EJ, et al. Poxvirus-based active immunotherapy with PD-1 and LAG-3 dual immune checkpoint inhibition overcomes compensatory immune regulation, yielding complete tumor regression in mice. PLoS One 2016;11:e0150084.

226. Ngiow SF, von Scheidt B, Akiba H, Yagita H, Teng MW, et al. Anti-TIM3 antibody promotes T cell IFN-gamma-mediated antitumor immunity and suppresses established tumors. Cancer Res 2011;71:3540-51.

227. Sakuishi K, Apetoh L, Sullivan JM, Blazar BR, Kuchroo VK, et al. Targeting Tim-3 and PD-1 pathways to reverse T cell exhaustion and restore anti-tumor immunity. J Exp Med 2010;207:2187-94.

228. Heninger E, Krueger TE, Lang JM. Augmenting antitumor immune responses with epigenetic modifying agents. Front Immunol 2015;6:29.

229. Gangadhar TC, Hamid O, Smith DC, Bauer TM, Wasser JS, et al. Epacadostat plus pembrolizumab in patients with advanced melanoma and select solid tumors: updated phase 1 results from ECHO-202/KEYNOTE-037. Ann Oncol 2016;27:1110PD.

230. Gangadhar TC, Schneider BJ, Bauer TM, Wasser JS, Spira AI, et al. Efficacy and safety of epacadostat plus pembrolizumab treatment of NSCLC: preliminary phase I/II results of ECHO-202/KEYNOTE-037. J Clin Oncol 2017;35:abstr9014.

231. Smith DC, Gajewski T, Hamid O, Wasser JS, Olszanski AJ, et al. Epacadostat plus pembrolizumab in patients with advanced urothelial carcinoma: preliminary phase I/II results of ECHO-202/KEYNOTE-037. J Clin Oncol 2018;JCO2018789602.

232. Kakavand H, Wilmott JS, Menzies AM, Vilain R, Haydu LE, et al. PD-L1 expression and tumor-infiltrating lymphocytes define different subsets of MAPK inhibitor-treated melanoma patients. Clin Cancer Res 2015;21:3140-8.

233. Pfirschke C, Engblom C, Rickelt S, Cortez-Retamozo V, Garris C, et al. Immunogenic chemotherapy sensitizes tumors to checkpoint blockade therapy Immunity 2016;44:343-54.

234. Lin RL, Zhao LJ. Mechanistic basis and clinical relevance of the role of transforming growth factor-beta in cancer. Cancer Biol Med 2015;12:385-93.

235. Massague J. TGFbeta in Cancer. Cell 2008;134:215-30.

236. Hanks BA, Holtzhausen A, Evans K, Heid M, Blobe GC. Combinatorial TGF- $\beta$ signaling blockade and anti-CTLA-4 antibody immunotherapy in a murine BRAFV600E-PTEN-/transgenic model of melanoma. Available from: https://ascopubs.org/doi/abs/10.1200/ jco.2014.32.15_suppl.3011. [Last accessed on 21 Jun 2019]

237. Jerby-Arnon L, Shah P, Cuoco MS, Rodman C, Su MJ, et al. A cancer cell program promotes T cell exclusion and resistance to checkpoint blockade. Cell 2018;175:984-91.

238. Spiotto MT, Rowley DA, Schreiber H. Bystander elimination of antigen loss variants in established tumors. Nat Med 2004;10:294-8.

239. Van Willigne WW, Bloemendal M, Gerritsen WR, Schreibelt G, de Vries IJM, et al. Dendritic cell cancer therapy: vaccinating the right patient at the right time. Front Immunol 2018;9:2265.

240. Twyman-Saint Victor C, Rech AJ, Maity A, Rengan R, Pauken KE, et al. Radiation and dual checkpoint blockade activate non-redundant immune mechanisms in cancer. Nature 2015;520:373-7.

241. Pauken KE, Wherry EJ. Overcoming T cell exhaustion in infection and cancer. Trends Immun 2015;36:265-76.

242. Emens LA. Cancer vaccines: on the threshold of success. Expert Opin Emerg Drugs 2008;13:295-308.

243. Berraondo P, Sanmamed MF, Ochoa MC, Etxeberria I, Aznar MA, et al. Cytokines in clinical cancer immunotherapy. Br J Cancer 2019;120:6-15. 